\title{
Analysis of the Role of the Community Empowerment Program in Strategic Plan Development Village at Semangga District of Merauke
}

\author{
${ }^{1}$ Yohanis E. Teturan, S.Sos., M.Si \\ ${ }^{2}$ Mulyadi A. Tajuddin, SH.,MH \\ 1 and 2 Department of Legal Science \\ Faculty of Social and Political Science \\ Musamus University
}

Doi:10.5296/ jpag.v5i3.8375 URL: http://dx.doi.org/10.5296/ jpag.v5i3.8375

\begin{abstract}
Analysis of the role of the community empowerment programs in strategic plan development village at Semangga district of Merauke. This research aims to analyze and describe village development strategy program utilization and factors that affect this research are carried out at Semangga Jaya village and Kuprik village. The method that is used in this research is qualitative descriptive and the analysis tool in the analysis of the use is exponential. The results of this research show that RESPEK program implementation is in compliance with the technical instructions, but the accomplishing at semangga village and jayakuprik village i.e. preferred physical program while the non physical program has not been implemented with good results for the study and the interviews in getting from research, need to be on the watch for the needs of the principals of the program.
\end{abstract}

Keywords: Evaluation Program, Empowerment Program, Strategic planning. 


\section{The Benefit of the Purpose}

As input for local governments are as well as scientists and observers issue empowering society as village. As for the benefits achieved in this research are as follows:

1. Policy and decision makers about the RESPEK program in order to comply with the real conditions in the implementation as well as be able to overcome the obstacles that arise in implementing the program.

2. The role of the community empowerment program to abuser through RESPEK and observer program.

\section{Introduction}

Province of Papua's special autonomy funds is run by the careful program strategic plan of development of village (RESPEK). Permadi (2009), one strategy to encourage the construction of villages for accelerating poverty reduction by providing a number of block grant funding of 100 million rupiah, each village in a year who donated to the community of special autonomy Fund. The Fund is managed by the community to determine its own needs. The utilization of the funds used for various fields in accordance with the development priorities covering the areas of health, education, economic empowerment and infrastructure. The program does have the RESPEK of orientation to empower communities living in the village, but the implementation has not been touched on aspects of empowerment that became the main objective of the program. To support the implementation of the program of activities on the level of RESPEK for the companion designated Ward and district level that comes from the local community.

As a common phenomenon that occurs that the community response to the diverse programs and often does not match the expected or planned. For example, when the village was invited by the facilitator of socialization and the district to the implementation of the program, many who choose not to attend for various reasons, the most important reason is to earn a living for her family because the program is implemented according to their opinion has not been directly delivering results for them. Whereas the village as a respected figure in the community groups and the extension of the hands of local governments is expected to be its driving force her participation in his community respectively.

The problems of poverty are complex enough to require intervention and it played all the parties together, well-planned and coordinated. But the controlling is as long as this tends to be partial and not sustainable. It is necessary to change the fundamental nature, planned, structured and systematic way as well as thorough in their poverty reduction efforts.

\section{A. Object- Impact Factors And Community Role}

Based on Explanation above, the formulation of problem related to the problem as follows:

1. What factors affect the process of community empowerment in RESPEK of implementation?

2. What is the role of community empowerment in RESPEK of implementation? 
3. To find out what factors that affect the process of implementing some of its empowerment.

4. To find out the role of community empowerment in RESPEK of implementation in the district Semangga.

\section{Review of the Related Literature}

\section{A. Meaning of Empowering}

"The sense of empowerment of the community, for the community accepted the role of and ideal position in the field of development and governmental fields is not a simple job. Position as a balanced partner can be realized only through the process of revamping all sigi, including consequence for the empowerment of civil society "(Sulistiyani, 2004).

Strengthening the institutional capacity of communities is indispensable so that the community is not as beneficiaries, but positioned as a partner of Government in each stage of development is therefore the role of the community in each of the courses conducted so great that the benefits of such a program could become a benchmark in the quest for development. Therefore the community is rather than as mere beneficiaries but more on the utilization of human resources, owned by the community itself.

"The notion of process "shows on potentially experiencing unplanned actions or steps that are chronologically specified systematic way reflects society's changing efforts staging is lacking or not yet empowered to empowerment, the process will refer to a concrete action undertaken gradually to transform a weak society, good condition, having knowledge, attitude, and practice (KAP) towards the mastery of knowledge, attitudes and skills conscious behavior skills is good" (Sulistiyani, 2004).

The theory presented above are explained that the knowledge, attitude and behavior is the key word in the implementation of the third factor such as empowerment is affecting every stage of empowerment by the community itself, since there are always changes in every action in line with the changes in any development process.

\section{B. Empowering Concept}

Empowerment is a series of activities to strengthen and optimized or potencies (in the sense of ability or competitive advantage) of weak groups in society, including individuals who have experienced the problem of poverty. In the process, the empowerment refers to the ability to participate, get the opportunity or access resources and services that are needed in order to improve the quality of life (both in individual, group and community in the broad sense). Community empowerment is a process where people, especially those with poor resources, women and groups that supported his best in order to be able to increase the prosperity independently. (Mardikanto and Soebiato, 2013)

1. Empowerment as a process of

2. Empowerment as a process of learning 


\section{Macrothink}

3. Empowerment as a process of strengthening capacity

Participation is an important component in the revival process of independence and empowerment (Craig and Mayo quoted by Heri Hikmat, 2010). We encourage people to be involved in the process so that they can pay more attention to life to gain confidence, self-esteem and has the knowledge to develop new expertise (Hikmat, 2010).

Public confidence is still very lacking while the son having issues therefore need to be seen as an issue that occurs in the body of society itself thus needs to be increased confidence and self-esteem of society for the creation of a decent life.

\section{1) Empowerment Steps}

"When does the empowerment to do? Sumodiningrat do in (Sulistiyani, 2004), empowerment is not forever, but until the target community can afford to be independence, and then released to be independent, though from afar guarded so as not to far again."(Sulistiyani, 2004).

As in tell in advance that the learning process within the framework of community empowerment will take place gradually. Stages which should be in the hitchhiking as follows:

a. Stages of awareness and behavior toward the formation of conscious behavior and care so feel in need of capacity building for itself.

b. Phases of transformation ability of insight knowledge.

c. Stages of increasing intellectual knowledge

\section{2) Empowerment Principles}

The fundamental principles of empowerment have been said by (Fahrudin, 2011). From the opinion of several experts including social workers; Solomon (1976), Swift Levin (1987), Kieffer (1981), Reppaport (1981and 1984), and Dobois Miley (1992), Fahrudin in 2011 can be summed up some of the principles and assumptions of empowerment, as follows:

a. Empowerment is a collaborative process, where social workers work together and client as partners.

b. The empowerment Process viewed the system as handle role client. Important (competence) and able to grant access the resources and opportunities.

c. Client must accept themselves as the causal agent, capable to influence change.

d. The competence gained through life experience.

e. Troubleshooting problem situations is based on the results from the complexity of the factors that influence (Solomon, 1976).

f. Social networks information is an important source of support for a bridge pressure and building competence and self-control.

g. People must participate in empowering themselves, and in achieving goals, understanding 
and results from the empowerment they need to articulate themselves.

h. Level of awareness and knowledge about activities to make changes is a major problem in the empowerment (empowerment) (Swift Levin 1978).

I. Empowerment is an attempt to gain the resources and the ability to use these resources in a way that is effective.

j. Process of empowerment is a process which is dynamic, ever-changing and evolving synergy, because problems have always had a great way of settlement.

k. Empowerment/empowerment can be achieved through its structure the congruity personal development and social structure and economy.

There are some principles of empowerment, as pointed out in the above then it can be summed up as follows. Empowerment is not only seen from one point of view, but in view of the various different viewpoints and ways of settlement are also different. Discuss about the empowerment itself not only on the person who became the driving force in the implementation of the program of all the parties involved but there is within the scope of its own. So everything becomes a shared responsibility not only on who manages the program itself but to all walks of life that enjoy such development.

\section{3) Strategies and Techniques in Community Empowerment}

Based on the book entitle empowerment participation and strengthening community capacity by Fahrudin, 2011. "In social work, understanding according to the need in client empowerment includes individuals, families, organizations and communities. Certainly the strategy and techniques of empowerment (empowerment) is in use varies according to its client. However generally, strategies and techniques of empowerment is seen from three forms of intervention social workers intervention the three forms of intervention of micro, mezzo and macro intervention is indicated to the individuals and families, intervention mezzo addressed to small groups, while the intervention macro to the Organization and the community. However, there are some experts who consider that empowerment is generally done collectively. However, there are some situations, empowerment strategy can be done effectively or solitary which is turn fixed with regards to collectivity".

\section{4) Factors Cause of Poverty}

"Poverty can briefly was defined as a standard low level of life, namely the existence of a shortage of materials on a number of levels or a party people are proud with the common standards in force in the concerned communities (Suparlan, 1993). States (Fahrudin, 2011), hereinafter referred to as the low life standards that directly affect health level looks, moral lives, their sense of self-worth and belonging in the poor.

The concept of the pass above can be understood that the cause of poverty is not only seen from standard life is experienced but judging from what does the cause of poverty that happens, because of the many factors that affect the occurrence of poverty such as level of education, health, and moral life and others who influence the cause of poverty and the 


\section{Macrothink}

inability of the community to meet the needs of everyday life. Hence the need for a change made by the parties directly involved in the implementation of poverty reduction programs.

\section{Implementation Program Strategy Planning Steps}

Village Development Based on RESPEK Program

\section{Basic Organizer}

The implementation of special autonomy abbreviated as (OTSUS) at the Provinces of Papua and West Papua as arranged in Regulation Law No. 21 of 2001, is essentially the granting of more extensive powers to the Government of Papua and West Papua Provinces, City District Government of all the Papua's people to set up and take care of themselves???. Besides the enactment of OTSUS basically wanted to do a fundamental change of the system of governance and the implementation of national development, implementation and bureaucratic with a decentralized system of Government is democratic, participatory, transparent and in accordance with the characteristics of the Community system as well as the needs of communities.

\section{Purpose, this program classified in to as follows;}

a. General Purpose

Speeds up the controlling poverty continuously towards self-reliance community with ways to improve the community as well as the enormous potential and institutional capability at the disposal of society to realize the program's food staple in humans i.e., nutrition, health, education, economy, and basic infrastructure.

b. Specific Purpose

1. Realization of human existence both individuals, families and indigenous peoples

2. Manifest the life in social, economic, political and legal culture of communities

3. Improving the quality of life of society, as well as Papua New Guinea, women

4. Increasing the potential and capacity of the community in any decision-making process, starting from the development planning, execution, control and preservation.

5. Improve institutional capabilities have to the village for facilitate peoples in the process of community empowerment in development programs

\section{Target and Program Location}

a. The main targets of the program beneficiaries are residents of underprivileged people's opinion in village by itself. His decision set forth through the planning process With the Community (PBM). 


\section{Mll Macrothink}

\section{The Principles of Self Respek PNPM}

a. Empowerment

b. The Alignments in the land of Papua

c. Underprivileged Communities to be represented both men and women in any planning process, decision, implementation of taking activities, ranging from group meetings, meetings of the tribe/clan/trains.

d. Protection of fundamental rights

e. Openness

f. Participant

g. Learning Participation together with

h. Alignments to women 


\section{Ml Macrothink \\ Journal of Public Administration and Governance \\ ISSN 2161-7104 \\ 2015, Vol. 5, No. 3}

Picture 1: Mechanism Disbursement of RESPEK

Province

SPM Submission

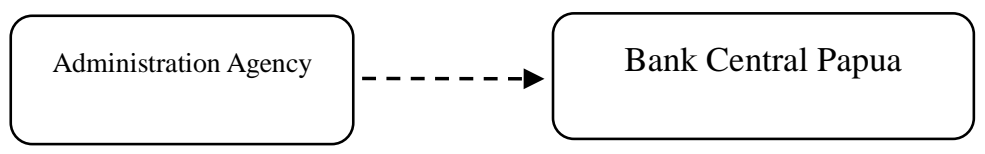

Step I: 55\% SP2

Step II: $45 \%$ SP2

DISTRICT

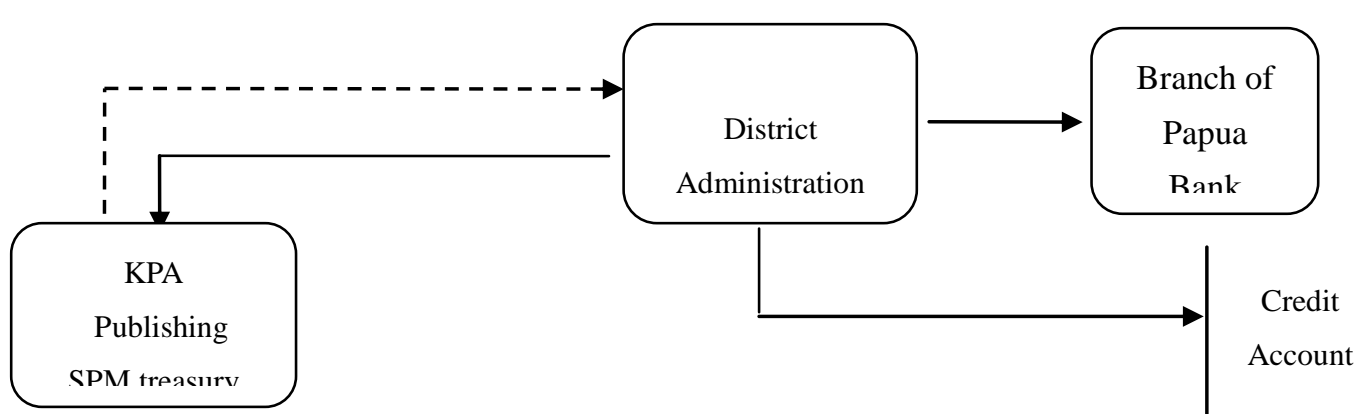

SPM Submission

Step I : $55 \%$

SP2

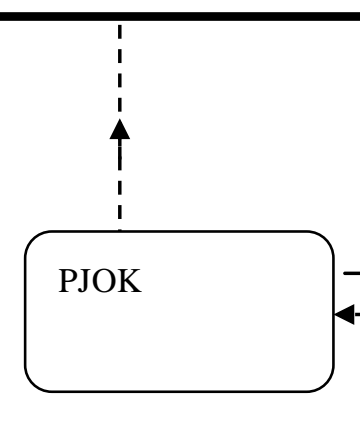

District

Submission of

Financing

Collective

Contract

Credit

Disbursement

Village

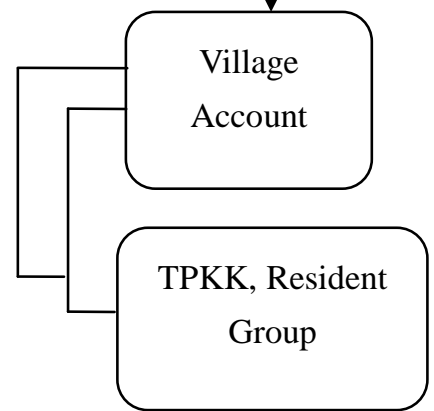

Distributing and thawing process

Administration and coordination process

Source: Village Development Strategy planning from RESPEK program 


\section{Macrothink}

\section{Program Agent}

Offender program at village is an agent who is domiciled or has a work area in the village.

a. Head of village

b. TigaTungku group

c. Organizer village activity team

d. Village colleague

e. Opinion writer's team

\section{Recipients Of The Peoples Program}

The success of development programs in villages determined by the readiness of the authorities and organizations conducting programs also influenced by a citizen readiness program recipients. This is due to the input program because of relief material and financial as well as a new service, effective when received positive use of the community.

\section{Research Method}

\section{A. Types of Research}

To discuss and review of community empowerment as well as to get an overview and a detailed explanation of the empowerment community Development strategic plan Program through village (RESPECT).Data collection is done using descriptive qualitative approach, which aims to get the data and information in the form of primary data and secondary data.

\section{B. Technique of Data Analysis}

Data analysis is an attempt to organize systematically records the results of observation, interview, documentation and more research to improve the understanding of the cases researched and presents findings for others (Moleong, 1998).

The analysis is the analysis of component part in use (Componential analysis). Looking for specific traits on any internal structure is a way of contrasting elements, done through observation and interviews with selected questions (contras question).

The first stage of the analysis of the data reduction process is focused on the selection, simplification, abstractly, and transformation of data from rough notes field. The second stage is the formulation of a set of data presentation information into a statement allowing the withdrawal of the conclusion. The third stage is the withdrawal of the conclusions based on the data reduction and presentation has been made. 


\section{A. Result and research discussion}

\section{Discussion of kuprik village}

The implementation of special autonomy for the Provinces of Papua and West Papua, as set in the Act No. 21 of 2001 essentially granting broader authority for the Government of Papua and West Papua of City Government and all the people of Papua to arrange and take care of yourself. With wider authority to arrange and take care of yourself according to the aspirations and needs of the community, then starting in the 2007 budget the Government of Papua and West Papua Provinces to allocate funds directly to Kampong sourced from funds in the form of OTSUS Block Grant amounted to an average of 100,000,000 million rupiah in every village.

1. The main target beneficiaries of programs less capable people's opinion in theirown hometown. The decision was set alongside the community planning through a process.

2. The target location of the recipient of the program is the entire village, that village have been integrated or passed through statutes and regulations in force with regard to the existing population.

3. Principles of Respect in carrying out development programs in villages should be able to develop their potential and capacities of the community group, which includes the village of the tribe and independence.

4. Protection of fundamental rights. The improvement of prosperity and quality of life of communities in the land of Papua, the need for the protection of the fundamental rights of the indigenous income sources of Papua. Program development strategy plan is a village (Ji) technical instructions operational (PTO) 2008.

\section{Implementing program analysis result respek kuprik village.}

Socialization is a negotiation process with the village community through meeting process for early explain about the goals, principles, policies, procedures and other matters related to the Respect and the agreements to determine each drafting proposal suggestion between the community of village in this RT, with the head of a local village in carrying out some of its programs.

Selection at the level of village, to select Communities in coordinating program activities village comprise three elements include; religious figures, Traditional leaders, and community leaders who are entrusted by the community to oversee the activities of the program in the process done by groups of people in the village, there is also the call to TPKK is responsible for the full course of development activities in the village.

The next step is community discuss together the needs and priorities of development in villages and consulted to determine the choice of the type of development activities that are priorities for funded. PNPM Mandiri program itself provided the manpower and technical empowerment consultant at district level in order to facilitate or assist the efforts of socialization, planning and implementation of activities. A proposal or idea from citizen will 
be the ingredients for preparing the Development Plan of the village.

Deliberation proposed activities always involve residents so that the program proposal is based on the fact from the society itself without any interference from any party including the accomplishing program, thus the process is done completely with the true aspiration because the public knows needs - the needs of their self.

\section{Benefit Program Development Strategy Olan Of The Village (Respek)}

The community recipient programs quoted based on book by Sutomo entitle Book Strategies for Community Development.

The success of the integrated village development programs is other than specified by the readiness of the authorities and organizations in the program also in influence by the recipient community preparedness programs. It is caused due to an input program is an effective aid in materials and financial as well as a new service, effective in getting responses to positive use of the community. The response especially in the form of the emergence of local activity in its sense of the next program through the local communities in the activities expected to reap the benefits of the program are running.

1. In the approach of empowerment that needed is local capacity growing to result improvement independently, the success of program is not measured by the background of organization managing but based on continuity benefit program to the citizen while from beginning to the end of program. The program who succeed an advantage growing in the long time is a program that is able to encourage next correction entirely through the prosperity correcting citizen or capacity advantage in the process of development.

Mardikanto, 1996 entitled empowerment citizen into public policy perspective.

Empowerment citizen is always said as a target group or empowerment citizen objects as lower citizen group or higher group, group of marginal citizen. This definition has taken an citizen in the lower position if it is compared with the first decision and development maker, the empowerment citizen facilitators and other decision maker have changed meaning of distributing target into benefit receiver.

1. In contrast to its position as a target for the community as beneficiaries have position which is equivalent to defining policies, stakeholder and facilitator of development.

2. The beneficiary is not the object/target of decent shoot in the low point of view by defining policies and the facilitator but established on a respectable position that needs to be served and facilitated as co-workers in the national program of development;

3. In contrast to its position as a aims have no choice/opportunities to bargain any material is has to be conveyed or should accept/follow it, beneficiaries have a bargaining position has to be respected to accept/reject the message from innovation facilitators. 


\section{MInstitute Macrothink}

4. The beneficiaries are not in the position of deciding policy below and the facilitators, but rather in the position of equal and even higher position in precisely the sense of having freedom to follow or reject the innovation is conveyed by extension officers.

5. The process of learning taking place of extension officers and recipients of benefits is not vertical (extension officers patronize benefit receiver), but the participatory process along.

The benefit of RESPEK program is very felt by citizens because it not only helps family economy, but also physical and non-physical activity. Physical activity consists of developing access streets from farmer house to their rice field, constructing process of water channel to irrigate farmer rice field, the other aid is nonphysical activity that consist of a funds to all mothers into women cooperation so that it can help family economy, the next aid is school facilities consist of uniform, shoes, school books that is given to the lower class students, the last aid is healthy facilities to the kids and parents lower class while they are fell help with this access healthy facilities. This programs and facilities are felt helping economy activity in lower class economy.

The citizens are fell help with this PNPM Mandiri RESPEK fund like a physical program. Before the program had appeared, the citizens fell difficulty into economy access while after this program appear, they don't fell difficulties. This program are consists of developing street to make easy economy access, building water channel has benefit to irrigate water into rice field. Construction of health care centre for mother and baby is not only fell by citizen but also for old age.

The availability of water for citizens is very important because it is the life source to the creatures, especially for citizens that lived in villages, therefore appearing of RESPEK program is very needed to help citizen into complying water in daily life.

\section{The role of citizens into developing process.}

The role of citizen quotes by Mardikanto, 1996 entitled Empowerment Society into Public Policy Perspective.

Empowerment society usually said as target group or object of empowerment society is lower group Society or marginalized society. This definition has positioned of society into lower group than the development decision maker, the facilitators of empowerment citizen has changed meaning of distributor into benefit receiver.

a. The role empowerment of citizen as benefit receiver is different with the role citizen in upper empowerment, likes decision maker, facilitators and first management development.

b. Benefit receiver is not main target that is underestimate worthy by decision maker and facilitators but it is decided by main position who need to be serviced and facility as work partner in succeed developing process.

c. The role as target that doesn't has choice or opportunity to bargain each material 
directly but it has to obey or receive decision.

d. Benefit receiver have bargaining position and decider has two choice, they are receive or refuse innovation from facilitators.

e. Learning process taking place between instructor and benefit receiver aren't vertically

(Instructor take a part as a partner) but it generally participant process.

The response of RESPEK program is showing satisfaction from society, it can be showed from citizen role of giving activity opinion, program organizing, activities act and evaluation activity that has been done with role from all act citizens as benefit receiver in this program.

The colleague has worked very nice because of this program is suitable to citizen. For example: in the rainy time they need a program to make their place is free from flood, so is in the dry season, while they hope anything can be included in this program based on their necessary. In this PNPM Mandiri RESPEK program every activity act has to involve citizen in activity because this program purpose is empowerment citizen, like physical activity, they will look for workers form original citizen.

\section{The Influence Factors of Program Activity}

The hindrance of changing stated by Soetomo, 2009 entitled Development Society in Arrange Change.

a. The changing process in the concept advantage in society development generally contributed to the mature society, it means they have advantages of thinking and specific behavior, it has adjustment and institutions system strongly moreover it always learned from one to other generations. It can be seen from point of view as the meaning of a changing process fast, the preventing of pursuer factors have an effort to give new elements that hoped as a changing process evaluation. SuerjonosSoekanto, 1998 around Soetomo, 2009 states kind of factors than can be reduce changing process, they are; 1)the less citizens relationship; 2) the obstruction of new knowledge; 3) citizen traditional behavior strongly; 4) consist of rules comes from tradition strongly; 5) worried feeling to the next situation that will make instability of culture; 6) initiative to the new thing strangely; 7) obstructions ideologically; 8) habitual; 9) orientation value to the habitual as a moral life.

The obstructions based on the statement above can be experienced in the process of introduction new idea or new work as changing form induction or planning changing. Anticipation to the obstruction factors should be done to the changing activity processes.

b. The anticipation impact as long as explained above, the changing is directed for the society to make changing process is fast, while the changing process fast doesn't guarantee resulting reach the desire for next time.

c. Physical and behavior changing are the changing process hope occurs into 
society around developing process in the norm life. This aspects consist of technology physical and behavior changing, physical technology is feel easy to observe likes the advantage of street and house developing, the using of motorcycle and in that environment in this time, the reducing of manure fertilizer into chemical fertilizer and so on. In contrary, behavior changing is felt hard to observe relatively because it is not concrete from the last research.

There is some opinions in this every program activity, they are agreement and disagreement because they has many opinions from society that can't be received by team program directly because of limited fund from society, generally the society will be conscious after they get benefit from this program.

The strange factors have bid impact because society always determine that a fund from PNPM Mandiri respek it is too large for TPKK, in fact a fund operational for TPKK is less, but they do their work liability as long as doesn't violate this rules, although they get pressure from others.

It is important to know that the fee for these team are too less and not adequate with minimum province fee, from this situation, the society have better hoping to his program through these team hard worker. They are expected getting best result without notice less fee. The program has limited accommodation so that they need more role from society directly and non- directly to help getting facilities in accommodation and finally can produce best result.

\section{The Explanation Of Semangga Jaya Village}

Putting in force autonomy has been arranged specifically in the UU no 21 year 2001 to give them capability broader to the province government in all Papua and west Papua and all Papua's society to arrange and organize their self. Based on the capability broader to arrange and organize their self that is suitable with aspiration and society requirements, then in 2007 government province in Papua and west Papua allocate a fund in every villages directly source from OTSUS figure Block Grent amount about a hundred million for every villages. The requirement for getting this fund are: 1 ) the main target are poor society based on village society opinion, 2) the village that is integrated or legal based on rules valid regulation and considering amount of village society, 3 ) in this implementation village program, RESPEK potency principle and capacity of village society contain of group, ethnic toward independency has to be expanded. 4) Protection to the general human rights, 5) the process of getting prosperity advantage and quality life of Papua society, general human right is needed to protect Papua original revenue. RESPEK program is given clue to the operational technique in 2008.

\section{Analysis Result of Respek Program In Semangga Village}

Socialization is the general meeting with society to discuss main goal, principle, rule, procedure, etc related with RESPEK program. In getting valid agreement, the result is gotten based on the opinion from every village leader and leader group of RESPEK program. 
This activity is started with socialization, program opinion, arrange verification program, planning, appointment, RAP arrangement, activity execute. In every village, the first execute program is done by TPKK team concern all society to inform benefit of RESPEK program so that they will be understood this program.

Every opinion that is given by society will be accumulated to consider the main priority based on the society necessary together with program activity. In collecting opinion of socialization program activity is done by society in Semangga village concern with all society. Transparency of this program is needed because society will know program execute so that there will be no suspicious or envy between society through fund needed by program execute in Semangga Jaya village, the involvement society from planning to evaluation process are very needed by society because it has impact with program execute in fact if they don't have involvement in this program generally, it will impact with it.

\section{The Benefit Of Planning Respek Program}

The citizen received this program quoted by Soetomo, 2008 entitled developing society strategy)

a. The successful of this program is not only considered by counselor participant preparation but also society also have similarity role. This is influenced by material program fell effectively than financial into public service. This program will be worked better if they get response from society. This response appears based on local activity that influenced by the last program while society hoped could take advantage from continuing program.

b. In the approaching process, we need developing of local capacity to result reparation independently, the success of this program doesn't conclude from organization group but how it will be useful by society in the future. The program will be success if it can be taken advantage in the future independently both of society prosperity and advantaging development society.

Mardikanto, 1996 entitled community empowerment in the perspective of public policy.

Community empowerment is always called with the target group or the object community empowerment referred to as society lower class or the original group, marginalized community. This definition has taken community into lower class than in the first of decision maker into developing process. The facilitators of society empowering and the leader of decision maker has been changed the word of distributing target into benefit receiver. This definition is classified into five term, they are: a) this condition is distinguished as society target take a role as benefit receiver that has equivalent status with decision maker, facilitator and developing decision maker; b) benefit receiver are not main target who is proper as lower society by decision maker and facilitators but it have to take into honorable position. They have similarity authority in getting public service and facility as work partner in development program; c) benefit receiver has an authority neutralize and respected to receive or refuse innovation from facilitator, in this case the position is distinguished as target that doesn't has choice or chance to honorable material given so that they should be obey all of rules; d) 
benefit receiver is not in the lower position than decision maker and facilitators, but they should get equal position or higher position. It is mean that they get choice to receive or refuse new innovation from investigator; e) studying process continue between investigator and benefit receiver actually doesn't having the character of vertically (investigator teach benefit receiver), but working together.

The main benefit of the developing program in the village is physical program, likes: molding process of street in village and deposit account for woman, but this program is focused in the physical program than nonphysical program so that the utilizing empowering of human resource of this program doesn't reach maximum goal as long as of society prosperity. The distribution of fund amount 15 percent for women don't managed maximally because they don't have knowledge and understanding about how to manage this money, so that it is impact of credit late.

Over all, the physical benefit of this program is clear but in non- physically doesn't clear, for example: productivity society through training process while it can build entrepreneur spirit to support developing program and continuity family life as well as the advantaging of economy condition.

\section{Society Roles of The Developing Process}

The role and skill of management(Jim Ife and Frank, 2006 entitled Community Development), there are many roles and practice that is categorized as role of giving facility is related with stimulation and supporter factor in the developing society process, the employee can use variety technique to make easier an effective process that become main factor to speed up action and helping condition of free movement into categorizing process of specific role that is identified as: socialization spirit, mediation and negotiation, developing consensus factors, group facilitators, applying skills and human resource, managing and personal communication.

A. Socialization spirit describes a part of important from working practices. It means that it has ability into inspiring, stimulating, moving, motivation people in action. The roles of society employee don't become individual people but they have to able to make other people engaged in activities in the community.

B. Mediation and negotiation of community workers often deal with conflicts of interest and value in society. The conflict often felt because of issues of personal power, but also the conflict very strongly felt by the public. Strong feelings can be a signal for the development of society because it indicates that the population has strong feelings against the people themselves and the conditions inside. But a strong feeling it could provide little comfort to a worker community which is trying to resolve conflict and developing consensus.

C. Support is one of the most important roles for a worker of the community because it provides support for people involved in various structures and activity of the society. This includes in it confirm the population, recognizing and acknowledging their value as well as their contributions, giving encouragement, 
willing when they are needed in terms of talking about something or ask other questions.

D. Building consensus or agreement in community development aims to answer the conflict approach taken outright in a variety of social interaction, economy and politics. In opposing values conflicts and various structures of competence so that they can be replaced with different value deal and various structures of cooperation is the main task for the workers in the development of the community.

E. Facilitators spend lots of time with community workers spent in various group, its success will greatly depend and rely on good attitude about the ability of a small group within the Association. A variety of groups from a wide range of groups had appeared to work from all communities will be involved including those from other groups, the structure of the Committee, the Group of planners, group awareness-raising, training groups, task groups, group reaction, advising on groups and determining local policies.

Participation in any process performed as much as -needed presence awareness from all parties to be involved directly in the process of development, because it is needed the participation and cooperation of all parties to support the sustainability of these activities.

The role of PJOK is important because they are in charge of operational activities at the level of districts and villages. If they are not present, this will have an effect on the evaluation of the activities undertaken by the community as such assessment work that exists in the villages are not only complementary but play a role in the level of the district, escort always takes over the role from PJOK regarding solving problems the absence greatly affects the evaluation of the activities undertaken by the society, thus it is becoming a problem for the citizens of the community.

in the implementation of the program, we have a prime target so that the process of targeted activities will be completed for 3 months but the facts on the ground showed very high community participation so that the program of activities going on for 2 months only. It is shown that this program has been completed sooner than the specified target. Therefore need to be given a motivation to the perpetrator programs in the Kampong regarding surveillance and control programs. In the implementation of the program has always held a race in the Kampong development activities so that in practice we always provide motivation to society so that in the implementation of activities, we have always reported the results of the work to the companion to assess the results of the work of these tenets and pass judgment in accordance with the agreement to be provided thoroughly from an activity that is intended.

\section{The Influence Factors of This Program}

Resistance factors of change based on Soetomo, 2009 entitled community development in drawing up a change.

a. Changing in the framework of community development generally addressed to a society that is already pretty well established in the sense already has a pattern 
of activities and a certain behavior patterns. They have a scoring system and a fairly entrenched institutional system not even uncommon already in biodiversity from generation to generation. If seen from the perspective of society as a process of changing acceleration, meaning that it contains anticipation towards restricting factors that have an important function in an attempt to incorporate elements of the new hoping can be a trigger for change. Soekanto Suerjonos, 1998 in Sutomo, 2009 put forward several factors that can hinder the occurrence of change, these factors are; 1) The lack of relationship with other societies; 2) development of science that inhibit; 3) the attitude of a very traditional society; 4) the existence of the interests that are already embedded with powerful; 5) fear of the inherent shakiness on cultural integration; 6) initiatives against things that are new or unfamiliar; 7) barriers that are ideological; 8) custom or habit; 9) an orientation to the value of that life based on custom or habit.

Barriers such as those already described above can also be experienced in order to introduce a new idea or new way of working as a form of a change in the induction or planning changing. the anticipation of the resistance factor against supposed to do on the overall process of activities in order to make changes.

b. The anticipation of the impact, as has been described before, the changes induced in the development community, among others, is intended to accelerate the process of change is happening. However by doing the acceleration changes alone have not ensured that the development process of guarantee yet to achieve the desired results.

c.Physical changes and changes in attitude, expected to occur in the community development process as it pertains to changes in various aspects of public life. These aspects include physical changes of technology and changes in attitudes, changes in physical technology is relatively easier observed, for example, a change from the dirt roads into paved roads, From the House of bamboo-walled home wall, from motorized transportation users become users of motor vehicles, from the use of manure into fertilizer and so on. Rather a change in attitude happening indeed relatively harder than observed because its nature is not a physical changing as clear as technology.

These factors greatly affect the course of program activities in the village where it is bringing in a reaction against the pros and cons of development being done with so this is already a common in villages, so the role required all parties to engage directly or indirectly to support the program, most parties play a role here consists of three elements which include: the Government's village, religious figures, custom character who serves as motivation, community awareness, foster and control the whole process of activity gradually; preparation, planning, execution and preservation program in accordance with the rules and mechanisms of the program as well as overseeing the management and use of funds by TPKK. 


\section{Macrothink}

\section{a. Conclusion}

Based on the results above, several factors can be summed up as follows:

1. The role of community empowerment in RESPECT in the village of jayakuprik and semangga villages had been carried out in accordance with the guidelines of the program. Some of the activities consist of the socialization program, program planning, implementation of development programs of physical and non-physical evaluation activities ended with has been expressed that the role of the community it is desirable in any implementation is done both physical and non physical program. The program continues to do so was able to overcome the problems that exist in society. While overall the program is very useful because people can feel the direct impact of the program.

2. In the event that invites the community to make changes, an inhibitor of factor can be reduced by paying attention to two things. First, the societies must feel that these activities be hers. Thereby, the next process is the community will feel responsible for the success of the program so that it will contribute to the optimum. Second, these activities support the deal and it is in the system. The expected positive impact of the community is contributing positively in the construction of the Kampong in General and specifically human development i.e., there has been a change in the behavior of society as a whole, although not yet enjoy the benefits of the program.

\section{b. Suggestion}

Based on the above explanation then follows some suggestions as follows:

- Need for attention and support from the local government through the function of controls in RESPECT of the implementation of the program in the village of Jaya Kuprik and Semangga Jaya villages. This is to ensure the sustainability of sustainability programs RESPECT and social transformation of the poor helpless being a powerless society can be realized.

- Need for the role of PJOK in district level supervise, control the course of the process of ongoing activities, not limited to administrative judgment on or written report but viewed overall processes that occur in the field, because all this happened is more the role of escort district and TPKK, so to know clearly about the problems faced by the community.

- Overall activity that took place still rests on the sheer physical activities. While the overall physical activity non is not done properly, so the fact that the community is helpless and still need help from the Government while the aim of the program is RESPECT of accelerating poverty reduction continuously self-reliance community by increasing the potential and capacity of the community as well as the ability of institutional belonging to community, realize the conditions of social life, economy, education, health, mental attitude and culture of communities as a whole. 


\section{BIBLIOGRAPHY}

2013 Profil Distrik Semangga Kabupaten Merauke

\section{Papua} ,2008 Petunjuk Teknis Oprasional dan Pedoman PNPM Mandiri Respek Propinsi

Fahrudin, 2011.Pemberdayaan Partisipasi dan Penguatan Kapasitas Masyarakat Humaniora. Bandung.

Harry Hikmat, 2010 Startegi Pemberdayaan Masyarakat Gerakan Program Mandiri Edisi Revisi, Penerbit Humaniora Bandung

Jim Ifidan Frank T, 2008.Community Development Alternatif Pengembangan Masyarakat di Era Globalisasi.Edisi KeTiga, Penerbit Pustaka Pelajar Yogyakarta

Martdikanto dan Soebianto, 2013 Pemberdayaan masyarakat Dalam Perspektif Kebijakan Publik Edisi Revisi Alfa Beta Bandung

Moleong, 2008 Memahami Penelitian Kualitatif Edisi Revisi PT Ramaja Rosdakarya Bandung.

Pasolong. 2005. Metodologi Penelitian Administrasi, Untuk Organisi Profit dan Non Profit, Lembaga Penerbitan Universitas Hasanuddin (Lephas). Makasar

Pembangunan Berbasis Masyarakat: Pembangunan Infrastruktur Tingkat Desa Jurnal.

Permadi, 2009.Efektivitas Pembangunan Jalan Kampung Dalam Program RESPEK Untuk Pemberdayaan Masyarakat Distrik Musatfak Kabupaten Jayawijaya.Tesis PPs Undip Semarang.

Pigai RESPEK dan Persoalan Ekonomi Masyarakat Kampung Di Papua. Refleksi Pastoral Atas Penyalagunaan Dana RESPEK Jurnal

Soetomo, 2008 Strategi - Strategi Pembangunan Masyarakat Pustaka Rajawali

Soetomo,2009. Pemberdayaan Masyarakat Merangkai Sebuah Kerangka Penerbit: Pustaka Pelajar Yogyakarta

Sugiyono, 2009.Memahami Penelitian Kualitatif, Penerbit CV. Alfabet Bandung.

Sulistiyani. 2004. Kemitraandan Model - Model Pemberdayaan Gava Media. Yogyakarta.

Terry G.R 1960 Principles of Managemen. Homewood Richrad D. Irin 